\title{
テーマ別研究動向（戦争・記憶・メディア）
}

——課題設定の時代被拘束性を越えられるか? -

\section{野上 元*}

\section{1 はじめに}

本稿に与えられた課題は, 「戦争・記憶・メデイア」をめぐる社会学的研究につ いて, 2004 年から 2009 年までのあいだに刊行された単行本を中心に扱いながら, その動向を紹介することである. 社会学的考察の対象としての「戦争」を中心に， 「記憶」と「メディア」を関連させて論じることが求められている.

とはいえ，そのような研究が比較的数多く見られるようになってきたのは近年の ことであるし，これが一過性のブームである可能性もないわけではない. であれば, いかなる課題設定において, それらがひとつの研究分野として成立しうる固有性を もっているかを意識しながら述べてゆくことが必要であろう ${ }^{1)}$.そこで以下ではま ず, 社会学はいかに戦争を主題化しえるのかというところから議論を始めることに したい.

\section{2 社会学の対象としての戦争 — 3 つの問題系}

戦争とは，（少なくともその当事者の一方以上をなす）国家による暴力（物理的 強制力）の発動である. 近代以降の社会では, 個人は自らの私的な利害のために公 然と暴力をふるうことは許されておらず, 私たちは, 対内的には警察, 対外的には 軍隊にそれを仮託し集約させることで，ひとまずの秩序・安寧をえている，いって みれば，暴力の集約によって共同体の輪郭が定義されるということだそそしてまた， 近代以降の社会において国家は, 暴力を公然と保有し, 所定の手続きのもと自由に 行使することのできる唯一の主体である. どのような国家においてであれ，原理的 な可能性として，たとえば市民の義務としての徴兵制や非常事態に際して市民権を 制限する戒厳令を排除することはできない.

もち万んそうした独占の結果, 国家に集積されている暴力は巨大なものとなり, その運用には高度に官僚制化された巨大な警察・軍隊組織が必要となる。初めから 日常性の水準に照準を合わせている警察に対し, 軍隊は, いわば非日常的な状態で ある戦争（への想定）を媒介にして, 軍事的諸制度で社会と関わろうとする。この

\footnotetext{
* 筑波大学大学院人文社会科学研究科国際公共政策専攻 gami.gen@nifty.com
} 
ようにまず，近代社会や国民国家の成立に深く関与している軍隊や戦争に関する本 質論的な諸テーマがある.

これに対し，具体的に発生した戦争，とくに 20 世紀に人類が実際に経験した 2

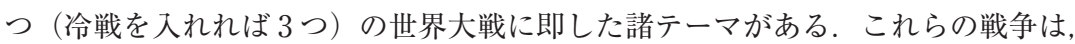
それまでの想定を遙かにこえた惨禍をもたらしたが，逆にいえば，それほどまでに 国家への暴力の集中を可能にしたものは，大衆社会状況に対応した「総力戦」とい う形態の戦争なのであった，極限まで社会から資源やエネルギーを引き出そうとす るそうした戦争は，国民の同意（戦争の大義名分や敵指導者・敵国民への憎悪）を 必要とし，そのための大衆説得（情報・思想統制, プロパガンダ）を不可欠なもの とする。逆に, 戦争による大量死・大量虐殺の事実や大衆説得の失敗は, 平和思 想・反戦運動の基盤となるだろう。同時に，戦争がもたらす「昂揚」は，さまざま な形態のミリタリー・カルチャーを社会に根づかせる。また，戦争遂行にとってよ り効率的で徹底的な資源の動員のために統制経済が採られるのと同時に，動員が一 方的な収奪だけでは立ち行かなくなると考えられれば，再生産を促し，人々の 「粒」をそろえるための社会政策・社会保障も計画されるようになる．大規模かつ 多領域にわたる社会への介入が平準化を引き起こし, 戦後における福祉国家や大衆 消費社会を準備するということも指摘されうる.

もちろんこれ以外にも，いわゆる連辞符社会学的な配置に応じた諸テーマがある. それらはじつにさまざまな領域に渡っており, 逆にいえば, そうした幅広い問題設 定を可能にするような総合性が，戦争という社会現象，なかでもとくに20世紀の 総力戦にはらまれているということである，換言すれば，戦争との対峙を通じて， 大衆社会論や社会学の諸テーマが構成されていったということでもあろう。戦争を めぐる社会学的探究における問題系の 2 つ目には, 総力戦という戦争の形態に対応 した諸テーマがある。

そのような総力戦は, その時代の人々に「戦争体験」を体験させる. 戦争体験者 とは，狭義には，国家のために戦場に動員され死の危険や誰かを殺す可能性にさら された元兵士たちのことであるが, それだけでなく, 総力戦の時代においては「国 民」であることそのものに付随して，戦争の時代を生きた人々一般を含めるように なっている.

戦争は, 個人にとっては理不尽・不合理にしかみえないようなかたちで（あるい は「運命」や「歴史」などの形式によって理解されるかたちで）それぞれの人生に 大きな作用を及ぼす。ささらに考えておかなければいけないのは，かれらは，死を迎 えざるをえなかった者たちを隣にして「生き残った」人々なのであった．かれらは 戦争後に, 自らの体験についてはもちろん, 友人や家族の死に関して過重な意味づ けを必要とするようになる。あれはなんだったのかと，自らの体験を理解し，ある いは次の世代にも継承させようとする試みが戦後の社会において一種の社会現象 一一時には神話——なるのである.

その多くは文学的あるいは政治的な分析のテーマとなったが, 日本においては社 
会学もまた，人々の意味世界をできるかぎり内在的に理解しょうとする感受性や技 法を鍛えてきたこともあって，戦争体験をテーマとしてきたのだった，戦争体験は， 人間の経験としては特殊なものであるけれども, 総力戦がそれを媒介したとき, そ の時代㧍よびその戦後における一般性を刻み込まれるようなものとなるのである.

\section{3 「戦争体験」の理解から「戦争の記憶」の解釈へ}

「戦争・記憶・メディア」の動向紹介である本稿は抢もに 3 番目の問題系, すな わち過去の「戦争体験」や，世代や時代を越えたその共有としての「戦争の記憶」 をめぐる「歴史の社会学」吕を扱抢うとしている。 もち万ん, そこでは, 戦争とい う対象がはらむ独特の負荷によって, 社会学におけるさまざまな志向性が複雑に絡 まり合っている.

ただ，この分野の研究に押いて大きかったのは, 研究者の世代的な背景による傾 向であったようにみえる．たとえば作田啓一（1922 年生）は,「戦争体験の今日的 意味」と題する論考で, 戦争体験を社会の問題として考えるための議論の場を設定 し(作田 1964), 戦争犯罪者を動かした集団心理についての分析を終えて「彼らは いくらかは私たち自身でもある」と述へ（作田 1967）, 中野卓（1920 年生）は 「個人生活史」という研究手法を自らの人生に適用して『「学徒出陣」前後—ある 従軍学生のみた戦争』を書き（中野 1992）, 森岡清美（1923 年生）は自らの出生 年に隣接する「死のコンボイ」にある決死の若者（1920-22 年生）たちの思いを遺 書の「重ね焼き法」を用いて浮かび上がらせようとする（森岡 1991）.

戦争の時代に生きた人々にとって「世代」とはたんなる論壇的な構築物ではなく て, 生死を分けかねない強力な条件であった，徵兵を始めとするさまざまな戦争の タイミングに扔いて, 出生の数年, あるいは学年を隔てるたった数カ月間の違いが, その運命に決定的な差異を生じさせえた. さらにまた, 時代の巨大な圧力がひとつ の共通体験を成形するということ, あるいは少なくとも, そういった信憑が共有さ れるということがありえた，そのような彼らにとって，「戦争体験」は特別な配慮 を必要とする用語だったのである.

その次の世代の社会学者は,「体験」を意識しつつも，ほんの少しでもそこから 逸れたかたちで戦争を扱㧍うとしたようにみえる．たとえば中久郎（1928 年生） は, 戦後の大衆文化を初めとするさまざまな領域に戦争の残響をみようとし（中編 $2004)^{3)}$, 山之内靖 (1933 年生) は, 戦時動員を終戦によって終わったものと考元 ずに，その後の「現代化」につながるものとして検討した（山之内ほか編 1995）. 秋元律郎（1931 年生）は, 「文中から自分を消しさることはできなかった」と述べ つつも, 戦時中の都市での戦争体験を, 生活に介入してゆく権力を媒介する住民組 織についての研究へと昇華させた（秋元 1974）。研究分野としての「戦争社会学」 の成立可能性を意識しながら, 高橋三郎（1937 年生）は, 共同研究によって「戦 友会」に調查を試み, あるいは「戦記もの」の追跡を通じて戦後社会の変容を押さ 
えようとした（高橋編 1983; 高橋 1988）。井上俊（1938 年生）は, 戦争を強烈に 体験した「戦前派・戦中派」の生き方／死に方を相対化する「戦無派」に抢ける 「死にがいの岥失」を論じた（井上 1973）.

彼らは，すぐ上の世代と同様「体験」を受けとめつつも，何らかの工夫によって それらを少しでも相対化しょうとし，あるいは別の表現を使えば，「体験」との距 離感自体を「方法」化していったように思われる。 もちろん彼らに抏いても同様に， 「体験」をその分析上の重要な特異点としていたのだった。

こうした状況に変化が訪れるのは，1995 年前後である．何よりも，「戦争体験」 の代わりに「戦争の記憶」という表現が過去の戦争の経験に関する言及やその集合 表象を表す観念として用いられるようになった ${ }^{4)}$ ，イアン・ブルマの『戦争の記憶 一日本人とドイッ人』の翻訳が 1994 年 12 月であり, 雑誌『現代思想』（青土社） 1995 年 1 月号が「戦争の記憶」の特集を組んで多くの論考を集めているほか，8月 には冨山一郎『戦場の記憶』, 高橋哲哉『記憶のエチカ一戦争・哲学・アウシュ ヴィッツ』が刊行される，雑誌『世界』（岩波書店）11月号は，安丸良夫と C. グ ラックの対談「戦後 50 年 記憶の地平」を収めている。 これらはすべて, 敗戦より 50 年という時間の経過において, 戦争の経験に関する諸観念を「記憶」という用 語において総括しようとする動きとみることができるだろう。過去の戦争の経験が, もはやその当事者でないことを自明の前提とするところから対象化され分析される ようになった，明らかにそれまでの「体験」研究と異なった前提から出発点してい たのである。

たとえば小熊英二は, 悲惨な戦争体験を共有したという実感とともにあった戦後 思想がその前提を失い, 結果として大衆ナショナリズムに飲み込まれていった過程 を論じている (小熊 2002)。 そこで目指されていたのは, 戦争体験そのものを理解 することではなく，それを思想史における有力な観念のなかの一つとして操作的に 扱うことで, 戦後思想史の記述が忘れてしまっていたものを掘り起こすことだった.

戦争体験の世代間継承/断絶をめぐる議論の戦後史について検討した福間良明 『戦争体験の戦後史一一世代・教養・イデオロギー』（福間 2009）も，そうした議 論の中心に『きけわだつみのこえ——日本戦没学生の手記』があるとしつつ, その 内容を分析するのではなく，この書物が，議論のいわば「磁場」を作り上げている さまを描こうとしている。『わだつみ』がいわば触媒となって戦争体験への共感や 反感が示され, 継承と断絶が論点になるのだが, それこそ総力戦を国民全員で「体 験」した効果であろう。本書も小熊と同様に,「戦争体験」を集合的な「戦争の記 憶」において扱おうとしている.

このように, 研究（者）の時代性とともにあり，ある意味で特殊な探究の対象で あった「戦争体験」が，歴史を書くために必要とされる観念の一つとして扱われる ようになったのが，1995 年前後の変化だった．それは敗戦後 50 年のことであった が, それは歴史的研究にとって, 冷静な把握を阻害するとされる同時代人の経駼が 相対化され, 時間的な距離によって客観的な対象化が可能になり実証的な研究が始 
められるとされる年月である。そこで「歴史」ではなく，「記憶」へと移行したこ とこそ，歴史認識論上の大きな変化であった，社会学は，この移行に際して，たと えば歴史学が示したような反発や躊躇をみせることなく，より広い分析の場を開く ものとしてむしろ歓迎したようにみえる，ただ，社会から戦争の「体験」が薄れて ゆくなかで，それを「記憶」へと置き換えること自体の意味を組み込んで課題を設 定した研究は数少なかったのではないか.

少なくとも，論じられる主題が，方法としての「記憶」にとって本質的であるか どうかはやはり重要である，たとえば先にも挙げた冨山（1995）は,「体験」論で はなく「記憶」論によって戦争 (戦場) を検討する。ここで「記憶」とは, 戦争や 暴力への探究における「日常化される動員」に対する切り込み口なのである。つま り, どうしても強固な当事者性が前提されてしまう「体験」の磁場を離れ, 自己同 一性が摇り動かされ，「記憶」の集合性に統合されたり分断させられたりする現場 に照準を合わせることで, 身体に刻みこまれる日常的な政治が作動する瞬間を観察 しようというのであった.

そしてその増補版（冨山 2006）には, 1990 年代半ば以降の「戦争の記憶」（ある いは集合的記憶論）ブームに対する若干の苛立ちが込められているようにみえる. 冨山によれば,「戦争の記憶」において何らかの「所有格」を持ち出すことに意味 を見いだせないという。その方法意識は,「体験」と「記憶」の落差や緊張関係に おいて生じていたといえるだろう.

一方，「原爆被害者調査」を丁寧に読み解く試みである濱谷正晴『原爆体験—— 六七四四人・死と生の証言』の問題意識は摇るぎなく（「記憶」ではなく）「体験」 に向かっており（濱谷 2005），本稿で扱っているような斯界の動向による影響を許 さない一貫性を有している，それは，20 年という年月を重ねてきた，調査票の丁 寧な読み取り作業の総括なのであり，いわば 1995 年前後の移行を等閑視している のである、調査票の一葉一葉はそれぞれ「被爆者」という存在を表象しており， 〈体の傷〉と〈心の傷〉の双方に関係する「人間」の形象を明確に浮かび上がらせ るためにも，「記憶」ではなく「体験」の意味論が必要だということであった.

とはいえ, 全体の趨勢としては, 戦後 50 年である 1995 年前後からの「戦争の記 憶」ブームによって, 数多くの研究が新たに産み出されるようになった. 過去の戦 争は遠ざかり体験者たちは次々と亡くなってしまっていたが，次節でみるように， 読解のためのアイディアによってさまざまな資料が新たに見いだされるようになる ことで, 一種のブームと呼べるような数の「戦争の記憶」研究が可能となったのだ った.

\section{4 「戦争の記憶」のメディア論的な読解}

1995 年以前の「戦争体験」の研究が, おもに体験者からの聞き取りや体験記や 戦死者の遺文などといった言語的な資料に焦点を当てていたのに対し,「戦争の記 
憶」研究では，視覚的な表象を中心とした非言語的な資料を採用するものが少なく ない．曖昧で捉えにくいかたちで存在している集合的記憶の対象化には，メディア 論的なアプローチが求められるということでもある.

たとえば森村敏己編『視覚表象と集合的記憶——歴史・現在・戦争』は, 視覚表 象に焦点を当てた集合的記憶に関する学際的な共同研究である（森村編 2006）. 視 覚表象と集合的記憶とを結ぶ論理はやや曖昧にみえるのだが, 逆にいえば, 記憶研 究に視覚表象分析をつなげるという方法には明確な有效性があり, その有效性の確 保の代わりに許されているある種の飖昧さは，それぞれの学問分野の固有性を超え た共同研究を可能にするということでもあるのだろう。そしてたとえば同書所収の 「トロント大学ソルジャーズ・タワーのイメージの変遷」にあるように, 視覚表象 を自ら解釈するだけではなく，その読み取り技法の変遷を意識すれば，捉えにくい 集合的記憶の動態を追跡することが可能なのであった（兼清 2006）.

「戦争の記憶」と視覚表象ということでいえば，好井裕明『ゴジラ・モスラ・原 水爆』が, 特撮怪獣映画に「戦争の記憶」, とくに「原爆」の記憶を読み込もうと している (好井 2007). その問題意識の源流には, 著者による少年時代の映画体験 があった．特撮怪獣たちの痛快な活躍の一方で少年時代の好井が「空気のように吸 収していた」原水爆のイメージを，数十年後に社会学者として見直そうというので ある。 それは確かに「戦争の記憶」なのであった，両者の落差には, 戦後社会や文 化に溶け込んでいる「戦争の記憶」の広がりを窥い知ることができるのである.

同様に，戦後社会におけるさまざまな「特攻」表象を分析した福間良明『殉国と 反逆——「特攻」の語りの戦後史』は，とくに任侠映画に「戦争の記憶」を読及込 もうとする（福間 2007）。特攻には戦後，「殉国」「反逆」「犬死」「純真」「反戦」 などさまざまな意味が読み込まれたが, 㭸憤の蓄積とその爆発という任侠映画の筋 書きが，理不尽な死を強制された特攻の記憶とのあいだに親和性をもっていたとい うことである．それらの映画は，特攻の死者たちよりも，むしろそのすぐ横にいな がら生き残った「特攻帰り」を描くことで, 無能で無慈悲な上司や硬直化した組織 への「反逆」を繰り返し示している.

両者とも, 知識人たちの思想にではなく, 大衆娛楽のなかに「戦争の記憶」の伏 流をみる，映画を題材とした分析であることは，戦争体験の個別・具体性にではな く, 社会意識, あるいは人々の無意識（への訴求）という水準に着目していること を表しているが，そのようなかたちで無限定に広がる「戦争の記憶」を特定・発見 できるかどうかは，ひとえに研究者の分析に扔いてどのような「切り口」を設定し， どのように解釈するかのアイディアによるものだとはいえよう．

そのように広がる「戦争の記憶」への注目を，マス・メデイアの作用の水準へと 移してみると，たとえば佐藤卓己『八月十五日の神話——終戦記念日のメディア 学』が,「八月十五日 $=$ 終戦記念日」という「神話」の成立とその維持を戦後メデ イア史のなかで追尾している。連合国へのポッダム宣言の受諾通告が 8 月 14 日， 降伏文書調印が 9 月 2 日であるにもかかわらず，私たちの敗戦のイメージは「八月 
十五日」という日付に拘束されている，佐藤が示したように，ラジオによる玉音放 送と新聞による終戦報道という二つの国民的メディア・イベントのコンビネーショ ンとして「八月十五日」は体験された（佐藤 2005）。マス・メデイアの時間意識は, 公共性へのある種の配慮において，歴史意識と日常的な時間とを媒介し，時に「神 話」を創り出してゆく.

記憶に関するメディアの作用ということでいえば，山口誠『グアムと日本人— 戦争を埋め立てた楽園』は, リゾート地グアムの姿に隠れてしまった「戦争の記 憶」の発掘作業である。ここで注目されているグアム島は, 日米開戦と同時に日本 軍に占領され，敗色濃くなる 1944 年 8 月に米軍に奪還された島であり，戦後はア メリカのアジア・西太平洋戦略の要となる軍事基地となる一方で, 有数の観光地と して開発されていった島である（山口 2007）。「記憶」というよりも「忘却」(= 「埋め立て」）を，観光の媒介作用において検討している点が本書の特色である. そ れらは「見せる/隠す」をめぐる政治の作動と結びついているのである. 強大な軍 事力と経済的繁栄の顕示／暗示関係（日米安保とアメリカ軍の存在／高度経済成長 と観光開発）が構造的に組み合わさっているこの島は, 「戦争の記憶」が絡んだ戦 後日本の「親米と反米」（吉見 2007）を読み解くための特権的な観測地点となって いる。

このように不定形で無限定な「戦争の記憶」という対象の特性自体に取り組もう としたのが, 先にも挙げた中編（2004）である.「戦後日本のなかの『戦争』」とい う本書の夕イトルからも, 日常性に溶け込む「戦争」すなわち「戦争の文化」「戦 争の記憶」の無定形性・無限定性に取り組もうという課題設定を感じることができ る. なかでもとくに伊藤公雄「戦後男の子文化の中の『戦争』」, および高橋由典 「九六○年代少年週刊誌における『戦争』」の二論文が，そうした課題設定を正面 から受け止めているといえるだろう，伊藤論文は, 大衆文化により媒介された社会 意識において, 戦争に対する価值観は戦中から戦後で連続しているという判断から, 戦後社会における「男の子文化」にみられるミリタリー・カルチャーを追跡してい る。また，高橋由典論文では，そのひとつの核として少年マンガ週刊誌の「戦争」 特集が追跡されている，受け手の刹那的な快楽のもとで消費されてゆく大衆文化に おいて (こそ)「戦争の記憶」が継承されているとみなすことができるというので ある。

このように，「体験」に比して，当事者性を曖昧にする分，「集合的記憶」の研究 は対象となりうる範囲を広げ，多様な題材とテーマをえることになる，そもそも 「体験者」が「いる」という事実の直接性（あるいはそのことへの分析上の信頼, その代償としての限定性）に比すれば，集合的記憶としての「戦争の記憶」とは， 目にみえるかたちであらかじめ存在しているものではなく, 調査者・分析者の社会 学的な対象化や操作によって初めて浮かび上がる曖昧なものである. とすれば, そ うした分析対象の「緩さ」をいかに締めてゆくか.ここでみてきたように，そのと き必要とされるのが, 視覚表象に対してであれ, マス・メディアの作用に対してで 
あれ，「記憶」を集合的に現象させている媒介性への丁寧な取り扱いなのである.

\section{5 「継承」という問題をめぐって}

そのような意味で, 方法的な工夫として注目するべき試みの一つに, 直野章子 『「原爆の絵」と出会う一一込められた思いに耳を澄まして』がある. 直野は, 広島 平和文化センターに所蔵されている「市民が描いた原爆の絵」の描き手に対する聴 き取りを行っている，絵を書いた体験者当人に「絵に达められた想い」を尋ねて回 っているのである（直野 2004）.

ここで「記憶」というとき，それはむしろ集合性に簡単には統合されえない体験 者の個別性を浮かび上がらせるためのものであり, 視覚表象としての「絵」も, 非 言語的な表象であることの重要性はもちろんのこと, それ単独で分析対象となって いるのではなく，体験者に語りを促す「引き金」のようなものにもなっていること が重要である. そして, その語りは理解されやすい物語をなすことのない, 物語化 を拒絶するようなトラウマ的な体験なのであり, 時に理解を拒絶する「空白」を何 度も浮かび上がらせるようなものになっているのである. そのためにこそ, 非言語 的な視覚表象としての絵が, 持ち出されている.

また, 野上元『戦争体験の社会学——兵士」という文体』も幾分似た方法的工 夫を採る（野上 2006）。野上はまず，長野県のある村で編纂された戦争体験記の文 集の執筆者に対して聞き取り調査を行う。執筆者に戦争体験記に込めた／込められ なかった「想い」を尋ねて回ったのである，いわば，体験者の語りと体験記という 資料の落差を確認しようとするのだが，そこから野上はむしろ「戦争体験を書くこ と」の源流にさかのぼってゆくような系譜学的な考察（戦争体験文学や軍人官僚た ちの文書に対する言説分析）を試みている.

体験者たちそれぞれの個別性・固有性にこだわり，絵の描き手から多彩な言葉を 引き出して，支配的な集合的記憶の物語に対して距離を取り続けようとする直野と, 個別的で局所的であったかれらの「体験」が,「書くこと」の媒介作用のなかで次 第に溶解し，共同体や社会のなかで集合化してゆくさまを探ろうとした野上という 対比はあるものの, ともに「記憶」研究が盛んな時代であることを意識しつつ, 数 多くの表象や言葉が遺される一方で体験者が裚われていくという現在を，むしろ分 析上不可欠な条件として考察にとりいれようとしている. 目指されているのは, 「戦争の記憶」の時代にあって, 集合性を構成しているような力をあぶり出すこと なのである.

そうした目標を掲げたとき,「共有」や「継承」を（倫理的にではなく）社会学 的に考えることは, 一つの突破口となるかも知れない.つまり, 体験や記憶の共有 や継承を直接の目的とするのではなく, それが課題とされるときに, 社会や人間関 係, 共同体のなかで何がどのように呼び出されているのか, という社会学的な発想 を出発点にすることである。 
そうした問題意識は，近年でいえば，浜日出夫編『戦後日本における市民意識の 形成——戦争体験の世代間継承』にも表れているし（浜編 2008）,「聞き取り」の 現場や関倸性そのものを丁寧に押さえつつ, 経験された過去の出来事への意味づけ を読及解いてゆこうとするライフストーリーの共同研究である『過去を忘れない

語り継ぐ経験の社会学』においても, 戦争の経験は重要な位置を占めている (桜井ほか編 2008). 後者の論集に扔ける問題設定をとくに強く内面化しているよ うにみえる高山真「原爆の記憶を継承する一一長崎における『語り部』運動から」 は，被爆者の語り手が「継承」の意味作用によって自己同一性を保持してゆくさま を指摘している（高山 2008）.

あるいはまた，時に個別性に閉じてしまう「体験」と集合性を前提にしてしまう 「記憶」との両者を相対化するためにも, 先にもあげた高橋の「戦友会」研究（高 橋編 1983; 新装版 2005）や，家族の枠組みにおいて「戦争体験」を検討しょうと している新田光子編『戦争と家族——広島原爆被害研究』（新田編 2009）の試みが きわめて重要である。「戦友会」や「家族」はともに, マス・メディア的な公共性 の手前にあって,「戦争体験」を語りあい,「記憶」として共有する親密圈や共同性 の場として特権的である. 前者は戦後社会のなかで「戦争体験」を語る場が限られ ていたがゆえに, 後者は生活の場が直接「体験」の場となったがゆえに, 考察の対 象として有効なのであった.

だから両者は同じように扱って良いような対象なのではなく，「兵士の戦争体験」 と「市民の戦争体験」という対比が意識される必要がある.「戦争体験」の共有や 継承は，そうした対比を生み出すとともに無意味化してゆく「戦後」という文脈，

とくに「冷戦」という戦争の形態に扔いて理解することが必要である（野上 2008）. 本稿でみてきたように,「戦争の記憶」研究は近年, 戦争体験者と向きあいなが らも, 一方で「体験」から離れ，いわばメディア論的な視点を導入することで, 多 様な題材を扱う自由をえた. 体験者が次々と喪われてゆく今後, その傾向はいっそ う強まることだろう。けれども,「戦争の記憶」に扔ける集合性を分析以前の前提 にしてしまったり，対象にはらまれているマス・メディア的な粗大さに引きずられ たりして，社会学的な感受性を荒くしてはならないはずである。 それこそそれらは， 総動員・総力戦の残㳯でもあるのだから. 研究の時代的制約を理解し, むしろそれ を分析の条件として反省的・積極的に取り込んでゆけるかは, この分野の今後の動 向にとって重要な要因となるだろう.

\section{[注]}

1）このうち「記憶・メディア」に関しては, 近年編纂された『社会学事典』（日本社会学会社 会学事典刊行委員会 2010) に「歴史と記憶の社会学」(浜日出夫編) という大項目に「メディ アと記憶」(伊藤守) という項目が設けられている. 日本の社会学における「戦争」研究の系 譜については, 高橋 $(2004,2006)$ を参照. 高橋（2006）によれば,「これが戦争社会学だとい えるものは，いまもって存在しない」という．高橋（1974, 1981）も参照されたい. 
2）「歴史の社会学」とその可能性については, 浜（2007）による整理と野上（2010）によるそ の検討を参照.

3）ただし中は先に挙げた編著のなかで，満州国という「国家」の崩壊を目撃した自らの体験を 語っている（中編 2004）。この意味では，上の世代のグループに入れるべき社会学者であろう. 中は同書の別の論文で,「経験は無意識裡に，つまり主観的な意識化を逃れた経過をいうとす れば，そのなかには何かの契機により体験として意識化されるものがあると解したい」と述べ ている.

4）もちろん管見のかぎりではあるが,「戦争の記憶」という表現には, 江藤（1958）, 中村 （1965）という先行例もある. ただ江藤は個人的な記憶について論じている.

\section{[文献]}

秋元律郎, 1974, 『戦争と民衆——太平洋戦争下の都市生活』学陽書房.

Buruma, Ian, 1994, The Wages of Guilt: Memories of War in Germany and in Japan, NewYork:

Farrar Straus Giroux. (=1994, 石井信平訳『戦争の記憶一日本人とドイッ人』阪急コミュ

ニケーションズ.)

江藤淳, 1958,「戦争の記憶」『財政』23(9).

福間良明, 2007, 『殉国と反逆——「特攻」の語りの戦後史』青弓社.

—, 2009, 『戦争体験の戦後史一一世代・教養・イデオロギー』中央公論新社.

浜日出夫編, 2008, 『戦後日本における市民意識の形成——戦争体験の世代間継承』慶應義塾大学 出版会.

2007, 「歴史と記憶」長谷川公一・浜日出夫・藤村正之・町村敬志『社会学』有斐閣.

濱谷正晴，2005，『原爆体験一一六七四四人・死と生の証言』岩波書店.

井上俊, 1973, 『死にがいの喪失』筑摩書房.

伊藤公雄, 2004,「戦後男の子文化の中の『戦争』」中久郎編『戦後日本のなかの「戦争」』世界思 想社.

兼清順子, 2006,「トロント大学ソルジャーズ・タワーのイメージの変遷」森村敏己編『視覚表象 と集合的記憶——歴史・現在・戦争』旬報社.

森村敏己編, 2006, 『視覚表象と集合的記憶——歴史・現在・戦争』旬報社.

森岡清美, 1991, 『決死の世代と遺書一一太平洋戦争末期の若者の生と死』吉川弘文館（補訂版 1993).

中久郎編, 2004, 『戦後日本のなかの「戦争」』世界思想社.

中村光夫, 1965,「戦争の記憶」『展望』77 (1965 年 5 月号).

中野卓, 1992, 『学徒出陣」前後—ある従軍学生のみた戦争』新曜社.

直野章子, 2004, 『「原爆の絵」と出会う一一込められた思いに耳を澄まして』岩波書店.

日本社会学会社会学事典刊行委員会編, 2010, 『社会学事典』丸善.

新田光子編, 2009, 『戦争と家族——広島原爆被害研究』昭和堂.

野上元, 2006, 『戦争体験の社会学——兵士」という文体』弘文堂.

2008, 「戦後社会と 2 つ戦争体験」浜日出夫編『戦後日本における市民意識の形成

——戦争体験の世代間継承』慶應義塾大学出版会.

，2010，「歴史と向き合う社会学——資料と記述をめぐる多様なアプローチにみる可能性」

『年報社会学論集』 22 .

小熊英二, 2002, 『〈民主〉と〈愛国〉一一戦後日本のナショナリズムと公共性』新曜社. 
桜井厚・山田富秋・藤井泰編，2008, 『過去を忘れない一語り継ぐ経験の社会学』せりか書房.

作田啓一, 1964, 「戦争体験の今日的意味」『思想の科学』 29.

，1967，『恥の文化再考』筑摩書房.

佐藤卓己，2005，『八月十五日の神話——終戦記念日のメディア学』筑摩書房.

高橋三郎, 1974, 「戦争研究と軍隊研究——ミリタリー・ソシオロジーの展望と課題」『思想』605. ， 1981，「戦争の『魅力』はどこにあるか」『現代思想』1981 年 1 月号.

，1988,『「戦記もの」を読む一一戦争体験と戦後日本社会』アカデミア出版会.

，2004，「日本におけるミリタリー・ソシオロジーの系譜——建部逰悟と高田保馬」大梶

俊夫・船津衛・杉山由起男・山崎純一編『現代の社会学 21 世紀へ』北樹出版.

—, 2006, 「日本における戦争社会学——昭和一○年代の動向」大橋良介他編『学問の小径

——社会学・哲学・文学の世界』世界思想社.

一編, 1983, 『共同研究 戦友会』田畑書店（新装版 2005 インパクト出版会).

高橋哲哉, 1995, 『記憶のエチカ——戦争・哲学・アウシュヴィッッ』岩波書店.

高橋由典, 2004 , 「一九六 $\bigcirc$ 年代少年週刊誌に抢ける『戦争』」中久郎編『戦後日本のなかの「戦 争」』世界思想社.

高山真, 2008, 「原爆の記憶を継承する一一長崎における『語り部』運動から」桜井厚・山田富秋・

藤井泰編『過去を忘れない——語り継ぐ経験の社会学』せりか書房.

富山一郎，1995，『戦場の記憶』日本経済評論社.

，2006，『増補 戦場の記憶』日本経済評論社。

山口誠, 2007, 『グアムと日本人——戦争を埋め立てた楽園』岩波書店.

山之内靖, ヴィクター・コシュマン, 成田龍一編, 1995, 『総力戦と現代化』柏書房.

好井裕明, 2007, 『ゴジラ・モスラ・原水爆』せりか書房.

吉見俊哉, 2007, 『親米と反米——戦後日本の政治的無意識』岩波書店. 